\title{
Protestas sociales y cuestión social en América Latina contemporánea*
}

\author{
Social Protests and Social Issues in Contemporary \\ Latin America
}

\author{
Protestos sociais e a questão social na América \\ Latina contemporânea
}

\section{María Virginia Quiroga** , Ana Lucía Magrini*** $^{* *}$}

\begin{abstract}
RESUMEN
En América Latina asistimos a un tiempo de efervescencia de protestas sociales, las cuales han permitido visibilizar un extenso abanico de actores, demandas y repertorios. Algunas luchas se articulan entre sí, pudiendo convocar múltiples protagonistas o suceder en distintos lugares; mientras que otras, se desarrollan como iniciativas eventuales y localizadas. Las demandas sociales son diversas, aunque en su mayoría reclaman los oídos de los medios de comunicación y la sociedad en general, procurando encontrar respuestas en los poderes gubernamentales. El presente artículo propone un abordaje y sistematización teóricoconceptual para el estudio de las protestas sociales en América Latina, para lo cual se plantea una mirada multidimensional e interdisciplinar que reconoce el carácter plural y heterogéneo de las protestas. Así, en un primer momento del texto, se argumenta que las mismas resultan catalizadoras de la cuestión social y expresiones de conflictos y de la conflictividad social en el marco
\end{abstract} Palabras clave: América Latina, cuestión social, democracia, pandemia, protestas sociales.

\footnotetext{
* Este artículo recoge resultados de procesos de investigación previos de cada una de las autoras, cuyos hallazgos y conclusiones son revisados y reformulados para esta instancia.

** Doctora en Estudios Sociales de América Latina por el Centro de Estudios Avanzados de la Universidad Nacional de Córdoba, Argentina. Docente e investigadora en la Universidad Nacional de Río Cuarto-Consejo Nacional de Investigaciones Científicas y Técnicas (CONICET), Río Cuarto, Argentina. E-mail: mvqui@hotmail.com

*** Doctora en Ciencias Sociales y Humanas por la Universidad Nacional de Quilmes, Argentina. Investigadora en la Universidad Nacional de Quilmes- Consejo Nacional de Investigaciones Científicas y Técnicas (CONICET), Buenos Aires, Argentina. Docente en la Universidad Nacional de Río Cuarto, Río Cuarto, Argentina. E-mail: analucia.magrini@ gmail.com
} 
de la democracia. En una segunda instancia, se intenta sistematizar sus principales demandas y repertorios; y, en tercer lugar, se profundiza en torno a los posibles cambios y desafíos de las protestas sociales en el marco de la actual pandemia.

\begin{abstract}
Latin America is witnessing a time of effervescent social protest, which has made visible a wide range of actors, demands, and repertoires. Some struggles are articulated among themselves, being able to summon multiple protagonists or happen in different places, while others develop as eventual and localized initiatives. Although social demands are diverse in their majority, they are on the media's eye and society, trying to find answers in the governmental powers. This article proposes a theoretical-conceptual approach and systematization for the study of social protests in Latin America, for which it proposes a multidimensional and interdisciplinary look that recognizes the plural and heterogeneous character of protests. Thus, at the beginning of the text, it is argued that they are catalysts for the social question and expressions of conflict and social unrest within the framework of democracy. In a second instance, it attempts to systematize their main demands and repertoires; thirdly, it delves into the possible changes and challenges of social protests in the current pandemic framework.
\end{abstract}

\section{RESUMO}

Na América Latina, somos testemunhas de um momento de efervescência de protestos sociais, os quais permitiram visibilizar uma ampla gama de atores, demandas e repertórios. Algumas lutas se articulam entre si, podendo convocar múltiplos protagonistas ou acontecer em diferentes lugares; enquanto outras se desenvolvem como iniciativas eventuais e localizadas. As demandas sociais são diversas, embora a maioria delas exija a atenção dos meios de comunicação e da sociedade em geral, tentando encontrar respostas nos poderes governamentais. O presente artigo apresenta uma abordagem e uma sistematização teórico-conceitual para o estudo dos protestos sociais na América Latina, para o qual se propõe um olhar multidimensional e interdisciplinar que reconhece o caráter plural e heterogêneo dos protestos. Assim, em uma fase inicial do texto, argumenta-se que eles próprios são catalisadores da questão social e expressões de conflitos e da conflituosidade social dentro da estrutura democrática. Em um segundo momento, procura-se sistematizar suas principais demandas e repertórios; e, em terceiro lugar, aprofunda-se em torno das possíveis mudanças e desafios dos protestos sociais no âmbito da atual pandemia.
Keywords: Latin America, social question, democracy, pandemic, social protests.

Palavras-chave: América Latina, questão social, democracia, pandemia, protestos sociais. 


\section{Introducción}

Tras la caída del Muro de Berlín, la disolución de la Unión de Repúblicas Socialistas Soviéticas y el derrumbe del proyecto comunista a nivel global, el sentido de la revolución entró en crisis. Una vez que las democracias occidentales y el sistema económico, político y mediático neoliberal fueron aceptados como un modelo político y social hegemónico, retornó nuevamente la cuestión de la resistencia en el debate de la democracia. En América Latina esa "silla" ha sido ocupada por nuevos movimientos sociales ${ }^{1}$ y por protestas sociales que enfrentaron las medidas de profundización neoliberal durante la década de los 90 y comienzos del siglo XXI. De modo más reciente - y al calor del cambio de siglo-, buena parte de los países de la región experimentaron el acercamiento entre la movilización social y los llamados "gobiernos progresistas" ${ }^{2}$; dicho vínculo no permaneció exento de roces y tensiones, pero puso en evidencia las posibilidades de los actores colectivos para involucrarse en la gestión estatal (Laclau, 2006; Ramírez Gallegos, 2006; Svampa, 2008).

Desde el 2015 en adelante, las protestas en resistencia retornaron paulatinamente al centro de la escena pública. La expansión territorial de los proyectos progresistas se vio estancada y reducida, y se fueron

1 En nuestra región los nuevos movimientos sociales (NMS) no se construyen bajo la identidad de clase exclusivamente, sino que parten de la configuración identitaria desde lo étnico, el género, los sectores rurales y urbanos. Se caracterizan por construir demandas que, en general, exigen un cambio de sistema y expresan resistencias respecto de los poderes institucionales hegemónicos (Estado, gobierno, justicia, poder legislativo, grandes empresas, medios de comunicación masivos, entre otros). Desde el punto de vista comunicativo, hacen uso de estrategias basadas en el contacto y en los medios de comunicación populares y alternativos. En cuanto a su vínculo con la protesta social, los NMS se distinguen de otros actores - que también hacen uso de la protesta- en que intentan superar el reclamo por demandas puntuales. Es decir, han construido demandas amplias que exigen un cambio en la estructura hegemónica imperante y que, por lo tanto, implican una lucha que supera la coyuntura de la protesta como evento (Magrini, 2011). Para un recorrido sobre la emergencia y características de los NMS véase, por ejemplo, de Sousa Santos (2007).

2 Se hace alusión a la ola de gobiernos que se inauguró con la elección de Hugo Chávez en 1998, en Venezuela, y las posteriores asunciones de "Lula" Da Silva en Brasil (2002), Néstor Kirchner en Argentina (2003), Tabaré Vázquez en Uruguay (2005), Michelle Bachelet en Chile (2006), Evo Morales en Bolivia (2006), Rafael Correa en Ecuador (2007) y Fernando Lugo en Paraguay (2008). Más allá de sus particularidades y diferencias, los nuevos gobernantes expresaron la intención de recuperar el rol protagónico del Estado, y dotar a las políticas públicas de una impronta progresista asentada en la reivindicación de los derechos sociales, la invocación nacional-regional y la movilización popular. 
consolidando gobiernos que hacían parte de un "giro a la derecha" en el mapa político regional (Ansaldi, 2017; Giordano, 2014; López Segrera, 2016). A su vez, las protestas sociales no han permanecido ajenas a la reconfiguración de la vida cotidiana y a los efectos de una multicrisis global de carácter inédito, signadas por la proliferación del nuevo Coronavirus o COVID-19.

Atendiendo al escenario aludido, en este artículo intentamos problematizar qué entendemos por protestas sociales y de qué maneras estas pueden operar como catalizadoras de la cuestión social, y de sus transformaciones recientes, en un determinado espacio-tiempo o contexto específico. Al respecto, es importante destacar que, en este escrito, procuramos pensar las protestas sociales en plural, es decir, a partir de su heterogeneidad, y como un objeto de estudio que no termina de calzar por completo en una disciplina o campo de saber delimitado. Creemos que justamente su especial riqueza se halla en esa resistencia de la temática a enmarcarse de un modo claro y preciso en un campo disciplinar autónomo.

Proponemos, entonces, comprender las protestas sociales desde un enfoque interdisciplinar que se nutre de contribuciones muy diversas, como la teoría política contemporánea de vertiente posfundacional ${ }^{3}$, en diálogo con los procesos de construcción social de sentidos; una mirada comunicativa, atenta a la lucha por la hegemonía mediática; y aportes del campo del trabajo social para la consideración de las mutaciones y transformaciones más recientes en torno a la cuestión social.

Creemos que el análisis respecto de las dinámicas de las protestas sociales se convierte en un elemento clave para formular nuevas preguntas al calor de los tiempos que vivimos: ¿Cómo protestar, resistir,

3 Este término ha sido abordado por Oliver Marchart (2009) para englobar un conjunto de perspectivas de estudio (como los enfoques de Jean Claude Nancy, Chantal Mouffe, Judith Butler, Slavoj Žižek, Alain Badiou, Jacques Ranciere y Ernesto Laclau, entre otros) que se ubicarían entre dos extremos. Un extremo es el fundacionalismo propio de la narrativa moderna, el cual afirma la posibilidad de establecer fundamentos últimos de lo social. Otro extremo es el antifundacionalismo propio del posmodernismo "vulgar" que anuncia la ausencia de todo fundamento en el que "todo vale". Es entonces entre estos dos extremos que se dirime el posfundacionalismo como una crítica a ambas narrativas, debilitando el status ontológico del fundamento último, pero afirmando la posibilidad de construir fundamentos relativos a sabiendas que todo fundamento será siempre precario y contingente. 
cuestionar, luchar, disentir en tiempos de pandemia? ¿Qué nuevos o no tan nuevos repertorios de protesta emergen cuando los colectivos, más o menos organizados, o los ciudadanos en general no pueden salir a la calle por un confinamiento orientado al cuidado de la vida? ¿Qué lugar queda para demandas materiales no saldadas cuando lo que aparece amenazado es la propia existencia? Estas son algunas de las preguntas que intentaremos pensar aquí. Nuestras respuestas están lejos de la pretensión de exhaustividad, pues es evidente que asistimos a un contexto en el que la única certeza es lo desconocido. Con todo, en tiempos de pandemia apostamos por el valor de pensar en común, de abrir el debate para formular nuevas preguntas y de hacerlo con cautela frente a una situación a todas luces inédita.

En cuanto a la organización del texto, presentamos una primera sección abocada a la definición de las protestas sociales desde un enfoque multidimensional, y que recupera sus dimensiones políticas, comunicativas, territoriales e históricas. Allí aparece la hipótesis de trabajo que atraviesa toda nuestra reflexión, a saber: las protestas sociales resultan catalizadoras de la cuestión social y expresiones de conflictos y de la conflictividad social en el marco de las democracias contemporáneas. Posteriormente, rastreamos las principales demandas y repertorios de acción de las protestas sociales en América Latina. En tercera instancia, avizoramos algunos hallazgos y desafíos que impone el escenario reciente para el estudio de las protestas sociales y sus articulaciones con la definición y redefinición de la cuestión social.

Finalmente, conviene precisar que en las primeras dos secciones de este artículo ofrecemos una revisión y sistematización teórica, extensa pero no exhaustiva, para el estudio de las protestas sociales como catalizadores de la cuestión social; al tiempo que presentamos algunos ejemplos ilustrativos en nuestra región, reconocidos a partir de hallazgos de investigaciones previas y en curso de las autoras ${ }^{4}$. Los resultados

4 Entre los principales productos de estas investigaciones se encuentran: un libro que recoge crónicas sobre protestas sociales en 17 países de América Latina y en el que se incluyen cuatro textos analíticos que abordan la protesta social como derecho a la libertad de expresión (Rincón y Magrini, 2011); artículos y capítulos de libros que profundizan en las representaciones mediáticas de las protestas sociales en la región, la lucha por la hegemonía política y las relaciones entre medios de comunicación y gobiernos: Rincón y Magrini $(2010 ; 2011)$. También, un libro que indaga sobre movilización social e identidades políticas en Argentina y Bolivia en la transición del siglo XX al XXI (Quiroga, 2017) 
de estas pesquisas fueron revisados y reformulados a la luz de la hipótesis de trabajo antes referida. Mientras que la última parte de nuestro escrito, referido a la coyuntura actual y las posibles transformaciones en las protestas sociales, tiene como hemos adelantado, un carácter más exploratorio y ensayístico.

\section{Un enfoque multidimensional de las protestas sociales en América Latina}

Una de las categorías que ha adquirido renovada notoriedad en trabajos e investigaciones recientes acerca de América Latina y conflictos globales, es la de la protesta social. Hablamos de renovada centralidad porque esta noción había sido ampliamente trabajada para caracterizar las dinámicas de las acciones colectivas en los países de la región a fines de la década del 90, receptando y resignificando las contribuciones de dos grandes líneas de investigación del tema: el enfoque norteamericano o de la acción estratégica (McAdam, McCarthy y Zald, 1999; Tarrow, 1997; Tilly, 1978; 1990)5 y la perspectiva europea o de los nuevos movimientos sociales (Melucci, 1994; Touraine, 1997)6. En ese

y otra producción colectiva referida a las articulaciones entre acciones colectivas y territorios en América del Sur (Souza Coelho, Basconzuelo y Quiroga, 2016). Vale mencionar, además, algunos artículos recientes que enfatizan el devenir de las protestas sociales en Argentina (Quiroga, Brizzio y Forlani, 2018), y en Brasil (Quiroga y Juncos, 2020).

5 A grandes rasgos, esta línea de análisis centra su interés en la organización de la acción colectiva, los participantes y sus motivaciones. Se afirma que los individuos deciden su participación en una acción colectiva sobre la base de consideraciones racionales; es decir, evalúan la disponibilidad de recursos internos (canales, repertorios, líderes) o externos (las oportunidades del contexto). Las bases de esta corriente se plasmaron en el libro de Dough McAdam et al. (1999), donde los autores señalaron tres factores clave para considerar en el análisis de la acción colectiva: estructuras de movilización, estructura de oportunidades políticas, y marcos de interpretación. Retomaremos algunos de estos elementos en este texto, concretamente en las dimensiones de análisis de las protestas sociales.

6 Este enfoque, también conocido como cultural-identitario, parte de enfatizar la novedad de los actores colectivos en el marco de la sociedad postindustrial, actuando al margen de organizaciones políticas y sindicales. En general, el estudio de los procesos macrocontextuales se complementa con una mirada en torno a la producción simbólica al interior de los movimientos sociales. Así, desde este prisma, una organización colectiva supone: identidad, solidaridad, comunicación, formas compartidas de ver y entender el mundo. Algunas de estas cuestiones también se retoman en nuestra propuesta de sistematización y análisis. Sin embargo, nuestro trabajo no constituye una sistematización acrítica o irreflexiva, sino que tiende al diálogo entre la bibliografía clásica sobre el tema y la teoría política de vertiente posfundacional, sin dejar de advertir algunas tensiones en los supuestos teóricos, ontológicos y epistemológicos de base. Para una revisión crítica de la literatura específica en torno a la acción colectiva, protesta social y sus posibles 
marco, las protestas sociales se presentaban como expresión contenciosa de actores colectivos que irrumpían en el espacio público para visibilizar demandas específicas, en un contexto signado por el retorno a las democracias y la profundización neoliberal en varios países de la región. (Auyero, 2002; López Maya, 2000; Schuster, 2005)

Entre los motivos que contribuyen a explicar el auge de los estudios en torno a la protesta social, vale citar la capacidad del término para captar el carácter segmentario de las diferentes acciones colectivas que se erigían como cuestionamiento y reacción a las medidas de achicamiento del gasto público y retraimiento del Estado. "Protesta" permitía referir tanto a una iniciativa en un solo lugar y en un único momento, como a varias acciones encadenadas y dispersas en diferentes espacios simultáneos; a la vez que invitaba a la apertura de preguntas diversas sobre quiénes se movilizaban, cómo lo hacían, y por qué o para qué llevaban a cabo acciones disruptivas.

No obstante, la noción de protesta social es portadora de dos ventajas aún más interesantes a la hora de abordar conflictos y procesos sociales, actuales y de largo aliento. En primer lugar, al ser analizadas desde un enfoque histórico y procesual, las protestas pueden pensarse como expresiones de conflictividades más profundas, cuyas trayectorias se extienden más allá de lo coyuntural o episódico. Ello supone distinguir conflicto de conflictividad social' , de modo que una mirada sincrónica de los conflictos puntuales (ya sean encadenados, dispersos o simultáneos) requiere complementarse con una lectura diacrónica atenta a las dimensiones histórico-procesuales que van delimitando dinámicas, trayectorias y ciclos de conflictividad ${ }^{8}$. En segundo lugar, la

vínculos con la teoría política posfundacional de Ernesto Laclau y Chantal Mouffe, véase Quiroga $(2013 ; 2017)$.

7 Calderón Gutiérrez ha formulado expresamente esta distinción, según la cual la "categoría de conflicto social es útil para observar y analizar un conflicto cuando es un visitante momentáneo de la sociedad, pero no da cuenta de una visión holística y de las situaciones que se producen cuando los conflictos se propagan, extienden y perpetúan. Entonces es importante introducir la noción de conflictividad, porque da cuenta de un proceso de conjunto, no de un hecho particularizado" (Calderón Gutiérrez, 2012, p. 48). Recientemente el libro colectivo, editado por Andrea Andújar y Ernesto Bohoslavsky (2020), también propone una interesante mirada histórico-procesual acerca de los conflictos sociales en algunos países de la región, al tiempo que recupera la relevancia del enfoque histórico para la comprensión de las dinámicas de la conflictividad en la que se enmarcan.

8 Resulta de especial relevancia la noción de ciclos de protestas, remitiendo a "una fase de identificación de los conflictos y la confrontación en el sistema social, que incluye 
categoría "protesta" no siempre estará guiada por un sentido emancipatorio ni será protagonizada exclusivamente por los sectores subalternos; "por el contrario, puede desarrollarse para oponer resistencia a cambios de carácter progresista y/o para recuperar banderas que no implican necesariamente rechazos al sistema o al modelo imperante" (Quiroga y Juncos, 2020, pp. 54-55). Esta precisión es relevante porque advierte que las protestas en sí mismas no se definen por un contenido esencial a priori, ni son exclusivas de actores en resistencia; pues, en efecto, diversos sectores pro status quo hacen y han hecho uso de la protesta social para reivindicar sus demandas.

Teniendo en cuenta estas ventajas y advertencias en relación con el tema, proponemos una definición amplia de las protestas sociales como catalizadoras de la cuestión social y como modos de expresión de conflictos sociales y de la conflictividad en el marco la democracia. Comenzaremos a desandar esta definición por el final, resaltando que las protestas constituyen un recurso válido de la vida comunitaria en democracia, y, más importante aún, una garantía del derecho a la libertad de expresión ${ }^{9}$. A través de ellas, diversos grupos, movimientos, ciudadanos e identidades colectivas luchan por hacer visibles sus demandas, sus reportorios y sus estéticas (Laclau y Mouffe, 2004; Magrini, 2011; Rincón y Magrini, 2010; Schuster, 2005). Si no hay posibilidades de apelar a las protestas sociales como vías de expresión, si los gobiernos las criminalizan, si los medios de comunicación las invisibilizan y estigmatizan, entonces, asistimos a un régimen democrático endeble o, al menos, restringido. En definitiva, las protestas sociales no

una rápida difusión de la acción colectiva de los sectores más movilizados a los menos movilizados" (Tarrow, 1997, pp. 264-265). En ese sentido, cabe remarcar que la transición del siglo XX al XXI está signada por un ciclo ascendente de conflictividad social en América Latina.

9 Al respecto Catalina Botero, relatora especial para la libertad de expresión de la Comisión Interamericana de Derechos Humanos (CIDH-OEA) durante el 2008 y el 2014, clarificó que "las manifestaciones públicas de todo tipo y, en particular, las que pueden calificarse como de 'protesta social' constituyen formas legítimas del derecho a la libertad de expresión. En materia de protesta social, la relatoría especial ya ha señalado que es una forma especialmente protegida "dado que en ciertas circunstancias es la única forma a través de la cual determinados grupos pueden ejercer de manera efectiva su derecho a la libertad de expresión y ser escuchados" (Botero, 2011, p. 57). Las cursivas son nuestras. En 2019, la CIDH publicó un informe sobre protesta y derechos humanos que profundiza en los vínculos con la libertad de expresión, además de enfatizar en la recurrencia a internet como un nuevo ámbito de disputa política. Referencia electrónica disponible en www. oas.org/es/cidh/expresion/publicaciones/ProtestayDerechosHumanos.pdf 
son lo otro de la democracia, sino una condición mínima para su funcionamiento efectivo y una garantía del derecho a disentir o a resistir.

Al mismo tiempo, nuestra comprensión de las protestas sociales las vincula estrechamente con la cuestión social ${ }^{10}$, en tanto las diversas acciones colectivas procuran hacer visibles los temas, problemas y conflictos que hacen parte de su definición en un contexto específico. Ello requiere precisar que la cuestión social no remite a una serie de asuntos establecidos de antemano, sino que "se particulariza en problemas sociales, que son a la vez expresión hegemónica del modo como se interroga, interpreta, resuelve y canaliza la misma" (Grassi, 2003, p. 22) ${ }^{11}$. En otras palabras, la cuestión social constituye el resultado de una lucha de sentidos por hegemonizar qué asuntos son definidos como "sociales" y cuáles pueden constituirse en "problemas públicos" que exigen alguna respuesta, estatal o de la sociedad en su conjunto. De allí que las protestas representan intentos por lograr inscribir ciertas demandas en la agenda de problemas públicos que conforman la llamada cuestión social.

Lo dicho anteriormente subraya que las protestas se ven alcanzadas, tanto por dinámicas propias de conflictos puntuales, detonantes más inmediatos o factores de orden coyuntural; como también, por dimensiones más estructurales, históricas y de largo alcance. A su vez, ese contexto histórico también opera en torno a las modalidades que adquieren las protestas sociales, desde la tradicional huelga hasta el ciberactivismo. Con ello queremos acentuar que no solo es relevante reparar en las causas inmediatas de los reclamos y en los contenidos específicos de las demandas; sino también en las trayectorias y ciclos

10 El origen del concepto data de finales del siglo XIX, expresión que era utilizada para denominar problemas sociales permanentes, que ya no podían ser resueltos por la vieja filantropía, y que se encontraban ligados especialmente a las consecuencias de la Segunda Revolución Industrial, el surgimiento de la clase obrera y la emergencia del pauperismo. Para Robert Castel (1997), la cuestión social es "una aporía fundamental en la cual una sociedad experimenta el enigma de su cohesión y trata de conjurar el riesgo de su fractura" (p. 20). Su carácter aporético radicaría, entonces, en que supone la producción de nuevos arreglos institucionales que intentan dar respuesta (a través de intervenciones mínimas o parciales del Estado) a los problemas que la misma cuestión social visibiliza; no obstante, al ponerse en marcha estos arreglos, quedan al desnudo las contradicciones propias sobre las que se funda el orden social, económico y político.

11 Cursivas en el original. 
de lucha en que se inscriben, las relaciones que van tejiendo, y las modalidades y repertorios que revisten.

En función de lo expresado - y atendiendo a los antecedentes propios y de terceros que mencionábamos en el texto-, proponemos una breve sistematización de cuatro dimensiones clave que se ven involucradas en las protestas sociales tal como las definimos antes. Ciertamente nuestro abordaje está lejos de la exhaustividad y con seguridad muchos otros aspectos podrían alertarse. No obstante, la distinción de dimensiones (políticas, comunicativas, históricas y socioterritoriales) nutre un enfoque que llamamos multidimensional, el cual podría resultar productivo a la hora de iniciar pesquisas respecto de las protestas, conflictos y conflictividades en la región.

Las dimensiones políticas implicadas en las protestas sociales, se vinculan estrechamente con la construcción de las demandas ${ }^{12}$. Las mismas remiten tanto a las solicitudes y reclamos que se formulan desde una carencia, ausencia, mala implementación o reivindicación de un derecho o bien público; como así también, las exigencias de transformación en el sentido o significado de un determinado fenómeno social o político. En ese devenir emergen una serie de relaciones de poder constitutivas a la protesta social: por un lado, los vínculos al interior del grupo que formula las demandas y, a su vez, con aquellos actores considerados como aliados; por otro lado, se conforman relaciones entre los demandantes y los destinatarios de los reclamos, los más habituales son el sistema político, los gobiernos, algunos poderes del Estado, o instituciones públicas que no están respondiendo, no han

12 En su abordaje de las identidades colectivas y populares, Ernesto Laclau (2005) parte de la consideración de la demanda como la forma elemental de la construcción del vínculo social. Para el autor, un grupo es considerado como la articulación de demandas heterogéneas y no como un referente en última instancia homogéneo. Esto resulta pertinente para comprender que los movimientos y organizaciones sociales no constituirían identidades absolutas, sino que inicialmente opera en ellos una construcción de equivalencias entre demandas en torno a un significante común. Pensando particularmente en las protestas sociales, Federico Schuster (2005) coincide en la centralidad de la noción de demandas para dar cuenta de la constitución de identidades colectivas. A su vez, desagrega la demanda en sus aspectos genéricos y específicos. Es decir, la misma puede interpretarse desde el elemento más amplio en el cual se inscriben los reclamos, por ejemplo, la conflictividad laboral; como también, a partir de aquellos aspectos puntuales que dan motivo concreto a la manifestación de la protesta, por ejemplo, despidos, solicitud de aumento de salario, mejores condiciones de trabajo, entre otros. 
querido o no han podido resolver determinado asunto que configura una situación problemática para los sectores movilizados.

Como hemos adelantado, no es posible definir apriorísticamente el contenido ni la orientación política de las protestas sociales; en otras palabras, estas no resultan patrimonio exclusivo de ninguna clase social o corriente ideológica. De modo que, es posible distinguir protestas que se configuran "desde abajo" y "desde arriba". Las primeras, se producen desde lugares de resistencia frente a poderes hegemónicos (públicos o privados) o frente a los gobiernos de turno (ejemplo de ello, son los piqueteros en Argentina, los Sin Tierra en Brasil, el movimiento indígena en Bolivia, entre muchos otros). En general, estos actores buscan, a través de movilizaciones y acciones de protesta, transformaciones sociales amplias que desafían al sistema político o al orden social establecido. Pueden, en circunstancias concretas, evidenciar cierto apoyo a medidas adoptadas por los llamados gobiernos progresistas; sin embargo, en su mayoría se orientan a visibilizar los límites de algunas de estas políticas para la resolución de problemas de fondo.

Las segundas remiten a protestas sociales configuradas desde el espacio público hegemónico (cuyos protagonistas suelen ser empresarios, terratenientes, grupos económicos, medios masivos de comunicación e iglesia, entre otros), quienes generalmente acuden a movilizaciones y manifestaciones cuando sus intereses (económicos, políticos, ideológicos, etc.) se ven afectados. En general, la construcción de las aflicciones de estos actores como problemas suele ocultar el carácter particular de sus demandas, y es frecuente que surjan medidas y acciones de protesta con motivo de restricciones directas o indirectas a los beneficios que ostentan.

Un ejemplo relativamente reciente en Argentina fueron los cortes de ruta realizados durante el 2008 por sectores agropecuarios. Los mismos reaccionaban ante la sanción, por parte del Poder Ejecutivo nacional, de la Resolución no 125 que estipulaba una modificación al esquema de retenciones aplicadas a la exportación de cereales y oleaginosas. Esta iniciativa polarizó el espacio público-político argentino entre quienes apoyaban la medida en beneficio de políticas de redistribución y quienes, por diversos motivos, la criticaban y se reconocían en el arco heterogéneo del "campo", opositor al gobierno de la entonces presidenta Cristina Fernández. 
Por su parte, las dimensiones comunicativas abonan la comprensión de las protestas como procesos de interacción (Melucci, 1994) y conexión social, donde se ponen en juego intercambios socioafectivos, emotivos $^{13}$ e ideológicos; se negocia y renegocia la construcción de símbolos comunes. La comunicación al interior del colectivo habilita la exteriorización de una o varias demandas a través de modalidades y prácticas diversas capaces de llamar la atención de los gobiernos, los medios de comunicación y la sociedad en general. Estas dimensiones, al igual que las políticas, se relacionan con la configuración de las demandas, pero en ellas cobran especial relevancia los repertorios, las modalidades y las estéticas a través de las cuales los actores movilizados eligen poner en escena sus reclamos.

Vale resaltar que los medios de comunicación masivos se presentan como espacios de lucha por la visibilización pública de los conflictos sociales y de los propios individuos o colectivos movilizados. Al mismo tiempo, en tanto actores políticos concretos, los medios también influyen - desde relaciones de apoyo o desaprobación mediática- en el éxito o fracaso de las protestas sociales. En ese sentido, permiten dirigir los focos de visibilidad sobre ciertos asuntos y problemas; y, más importante aún, proporcionan "marcos de interpretación" (McAdam et al., 1999) que nos dicen cómo pensar los hechos de protesta que difunden o cómo concebirlos.

La estrategia de interpretación que generalmente promueven los grandes medios de comunicación es la estigmatización como delincuentes de quienes reclaman o realizan protestas en resistencia. De allí que el problema no solo radica en que hay ciertas demandas (como las indígenas, de las comunidades afrodescendientes, de las mujeres, de los desempleados, entre otras) que no son registradas por los medios de comunicación y, cuando los medios hegemónicos las abordan, lo hacen desde lógicas que resultan nocivas para la convivencia democrática, la promoción de la tolerancia y el respeto por la diversidad (Magrini, 2011). Por ello, ciertas protestas sociales de tipo contra hegemónicas suelen construirse desde estrategias de comunicación al-

13 Remitimos al lector a un trabajo reciente que en pocas líneas sistematiza la diversidad de perspectivas hoy disponibles para el estudio de las emociones y la dimensión afectiva en relación a las protestas sociales Basconzuelo (2020). 
ternativa, que van más allá de los medios masivos y que se sustentan en la comunicación cara a cara, en el desarrollo de medios propios, comunitarios o populares, como también en la recurrencia a las redes sociales y los foros virtuales.

Adicionalmente, es innegable que las protestas se despliegan en contextos históricos específicos y en permanente articulación con los rasgos y caracteres propios de una época (Calderón Gutiérrez, 2012; Tarrow, 1997; Tilly, 1978). Ello remite a las dimensiones históricas $o$ de la temporalidad, las cuales combinan un estudio sincrónico de los conflictos puntuales, con un análisis diacrónico de aquellos aspectos más estructurales que reconstruyen la trayectoria de la conflictividad social. Un ejemplo especialmente ilustrativo de la relevancia de las dimensiones históricas a la hora de estudiar las protestas sociales son las luchas de las mujeres, un colectivo que en su amplitud y diversidad ha tomado notable visibilidad pública a partir de las marchas del $8 \mathrm{M}$ convocadas a propósito del Día Internacional de la Mujer. Ciertamente se trata de una iniciativa que ha adquirido un carácter inédito en la actualidad, por su masividad, por la creatividad desplegada en sus intervenciones, y por su desarrollo simultáneo en varias ciudades latinoamericanas; sin embargo, no podría desconocerse que la lucha de las mujeres se inscribe en una amplia trayectoria y que ha transitado por etapas y ciclos de conflictividad muy diversos en cada uno de los países de la región.

Finalmente, las dimensiones socioterritoriales también juegan un rol destacado a la hora de comprender a las protestas sociales en su carácter situado (Tamayo, 2016; Traugott, 2002). El territorio aparece como el lugar que alberga la construcción de lazos afectivos y simbólicos involucrados en las protestas, pero también es el locus del conflicto por la defensa y preservación de los bienes públicos (Svampa, 2006). En definitiva, se trata del espacio habitado "donde la historia dialoga con el presente y permite, a partir de reminiscencias de esta, también construir una idea de futuro o incertidumbre" (Carballeda, 2015, p. 4). Para el citado autor, el territorio marca los bordes de las acciones colectivas, pero se trata de fronteras en constante movimiento y disputa; de este modo, es capaz de influir en las modalidades que adquirirán las protestas, y estas, a su vez, modifican el territorio y a los sujetos o actores que protestan. 
Estas cuatro dimensiones abonan un enfoque multidimensional para el análisis de las protestas sociales en tanto iniciativas complejas, plurales, relacionales, y susceptibles de permanente cambio. En ese sentido, los aspectos políticos, comunicativos, históricos y socioterritoriales contribuyen al estudio de cómo se configuran y reconfiguran las dinámicas de la acción colectiva, recreando las circunstancias específicas que rodean a una protesta social en particular, como también la trayectoria de conflictividad en la que se inscribe.

\section{Hacia un mapa ilustrativo de demandas y repertorios}

En definitiva, las dimensiones desarrolladas en el apartado anterior adquieren importancia a la hora de definir a las protestas sociales e intentar construir un mapa preliminar que permita vislumbrar algunos ejemplos ilustrativos de la diversidad de actores protagonistas, destinatarios, demandas, repertorios, alianzas, entre otras cuestiones relevantes involucradas en las mismas. En esta sección, nos centramos en el análisis de dos de esos criterios clave: las demandas (Laclau, 2005; Quiroga, 2017; Schuster, 2005) y los repertorios de acción. (Magrini, 2011; Quiroga 2017; Schuster, 2005; Tarrow, 1997)

Comenzaremos por distinguir las diversas demandas que articulan el accionar colectivo de las protestas en nuestra región, entendiendo que se trata del reclamo o reivindicación de un problema o, en otras palabras, de una insatisfacción respecto de la que se exigen respuestas. Vale reconocer, al menos, cuatro grupos predominantes de demandas.

El primer grupo refiere a las eternas deudas de América Latina, es decir, demandas históricas que dieron origen a diversos procesos de lucha y resistencia en el continente y que, a pesar de las experiencias reformistas que se vivieron en varios países de la región, aún continúan pendientes. Estas demandas se configuran en torno al derecho a la tierra, la reivindicación del trabajo, la defensa de los recursos naturales y el mejoramiento en la calidad de vida con acceso a educación, alimentación, salud y vivienda digna, entre otras.

Para ahondar en algunos ejemplos, vale considerar que la demanda por la tierra aparece históricamente ligada a la cuestión indígena, no solo como lucha por la mejoría en las condiciones materiales de vida, sino 
también como reclamos de cambio en la cosmovisión de mundo imperante. Es decir, el vínculo de los colectivos indígenas y afrodescendientes del continente con su territorio supone que sus prácticas, creencias y cosmovisiones dependen de la relación que entablan con el medioambiente. Un caso ampliamente referenciado es el movimiento de los productores de coca, en Bolivia, sobre todo desde la asunción de su máximo referente, Evo Morales, a la presidencia del país andino en el 2006 (hasta el golpe de Estado que lo destituyó del cargo en 2019). Durante la gestión de Morales, un importante sector de los campesinos pertenecientes a pueblos y naciones indígena-originarios manifestó su apoyo y logró participar de la gestión estatal, alentando la construcción de un Estado Plurinacional que quedó plasmado en la Constitución política del Estado aprobada en 2009. Algo similar ocurrió inicialmente en Ecuador, aunque allí el movimiento indígena es aún más heterogéneo; desde la asunción de Rafael Correa en 2006, el país fue incorporando principios como el derecho colectivo de los pueblos originarios y de la naturaleza en el texto constitucional del 2008. La fortaleza del movimiento indígena ecuatoriano cobró también visibilidad durante las extensas jornadas de protestas en octubre de 2019, reaccionando a las medidas de ajuste impuestas por el actual presidente Lenin Moreno. Finalmente, otros ejemplos que colocan a las demandas de los pueblos indígena-originarios en el centro de la escena, remiten a las experiencias del Movimiento Zapatista en México, y algunas organizaciones indígenas en Paraguay, Guatemala, Colombia y de la comunidad Mapuche en Chile y Argentina.

Por su parte, las reivindicaciones en torno al trabajo giran en torno a los reclamos por mejoras en las condiciones laborales, principalmente la puja salarial, como también a la demanda por empleo formal o simplemente por acceso al mercado de trabajo. El proceso de fragmentación de estas demandas se produjo a inicios y mediados de los 90 con la profundización del modelo neoliberal en la región y el proceso de reforma del Estado. En la actualidad estas exigencias siguen vigentes en un contexto en que las ha debilitado a partir de la reedición de políticas económicas que han traído mayor flexibilización, deterioro en el poder adquisitivo de los salarios e, incluso, pérdida de puestos de trabajo. Vale aclarar que conviven en este campo las luchas que se expresan a través de las tradicionales organizaciones sindicales, con nuevas formas vinculadas a empresas recuperadas, cooperativas de la economía popular y movimientos de desocupados. 
El segundo grupo de demandas remite a los derechos humanos. En general las agrupaciones defensoras de esta materia se conforman por familiares de las víctimas de los hechos producidos por gobiernos dictatoriales a inicios de los 70, especialmente en los países del Cono Sur, exigiendo memoria y justicia. Así, madres, abuelas e hijos e hijas de desaparecidos en dictadura buscan respuestas y visibilizan, ante los ojos de la sociedad, los nombres y los rostros de las víctimas del terrorismo de Estado. Mirando también a la región sur del continente cabe considerar que, en el caso de Colombia, estas demandas no están asociadas a un pasado dictatorial, sino a atentados a los derechos humanos producidos en contextos de hostilidad y terror durante períodos democráticos. Puede observarse una dinámica similar recientemente en México a partir de la problemática del narcotráfico.

Es posible ubicar en este grupo de demandas, reclamos por los derechos políticos, la libertad de expresión, el derecho a la movilización y la participación con garantías de preservación de la vida, por último, luchas por el derecho a disentir en un contexto democrático frágil o endeble. Estas reivindicaciones han sido núcleo del accionar de organizaciones pro derechos humanos que pretendieron denunciar y visibilizar la violencia del conflicto armado en países de Centro América como El Salvador, Nicaragua y Guatemala.

Finalmente, pueden incluirse en esta categorización de demandas las reivindicaciones que ponen el foco en el rechazo a las persecuciones ideológicas, a la criminalización creciente de la protesta social, el asesinato de líderes sociales y de jóvenes pobres en manos de la policía y fuerzas de seguridad del Estado. En países como Argentina, Brasil, Chile y Colombia este tipo de reclamos ha sido especialmente perceptible en los últimos años.

Por su parte, el tercer grupo de demandas apunta a las luchas de género y la diversidad. Este conjunto abarca desde las protestas por la violencia doméstica, la desigualdad en cuanto al acceso y las condiciones laborales, hasta los derechos de la comunidad homosexual y LGTBI+ ${ }^{14}$. Podemos decir que un elemento representativo en estos movimientos es la lucha por la tolerancia y la diversidad; se trata entonces de hacer

14 Colectivo de lesbianas, gays, transexuales, bisexuales y otras identidades no binarias. 
visibles otros modos de ser personas, de ser ciudadanos y de ser familias. Esta es quizás una de las demandas que ha puesto en cuestión las bases más profundas de nuestras sociedades no solo en lo cultural, lo social y lo religioso, sino también en lo político y económico.

El silencio parece ser una estrategia central en las protestas en torno a la problemática de la violencia de género. Ejemplo de ello es el colectivo Mujeres de Negro en Uruguay, quienes se manifiestan contra este abuso todos los primeros jueves del mes desde abril de 2007. También las masivas marchas y concentraciones, como las que propone el colectivo Ni una Menos en Argentina, desde marzo de 2015, y los Encuentros (pluri)nacionales de las mujeres y disidencias para poner en escena la problemática de la violencia patriarcal y la falta de libertades en materia de derechos sexuales y reproductivos.

Finalmente, como cuarto grupo encontramos las demandas de tercera generación. Se alude aquí a un amplio abanico de reivindicaciones ciudadanas como el derecho a la información, la exigencia por la responsabilidad social de las empresas privadas y las demandas de los movimientos ecologistas - principalmente en reacción a la expansión del extractivismo-. Muchas de estas iniciativas se encuentran articuladas con otras luchas descritas anteriormente, sin embargo, a partir de la emergencia de nuevas agrupaciones que no necesariamente se desprenden de movimientos indígenas u obreros o de grupos defensores de los derechos humanos, las hemos incluido en esta categoría. Una característica distintiva de estos grupos es que hacen uso frecuente de estrategias de comunicación alternativa (en relación con la comunicación masiva) y apelan a las nuevas tecnologías como medios de expresión.

$\mathrm{Al}$ respecto, y siguiendo las observaciones de Svampa (2008; 2012), podría señalarse el giro ecoterritorial de los conflictos sociales durante la última década, en consonancia con la profundización de un modelo extractivista en algunos países de la región ${ }^{15}$. Así, la explosión de conflictos socioambientales se hace visible "en la potenciación de las

15 El modelo extractivista puede ser comprendido como aquel patrón de acumulación basado en la explotación a gran escala de recursos naturales, así como en la expansión de las fronteras hacia territorios antes considerados improductivos (Svampa, 2012; Svampa y Viale, 2014). 
luchas ancestrales por la tierra, de la mano de los movimientos indígenas y campesinos" (Svampa 2008, p. 19), como también "en el surgimiento de nuevas formas de movilización y participación ciudadana, centradas en la defensa de los bienes naturales, la biodiversidad y el ambiente" (Svampa, 2012, p. 19). En el próximo apartado avanzaremos en torno a esta cuestión, en tanto la pandemia actual pone de relieve la degradación ambiental y la necesidad de aunar luchas sociales con perspectiva crítica y propuestas alternativas.

Es importante subrayar que la sistematización de las demandas que aquí proponemos, constituye solo uno de los tantos modos en que podría representarse la extensa variedad de reivindicaciones que visibilizan las protestas sociales latinoamericanas. Al mismo tiempo, queremos señalar que ninguna de las demandas aludidas es absolutamente independiente, sino que están atravesadas por una multiplicidad de brechas; en definitiva, los conflictos de clase se entrecruzan, por ejemplo, con los de raza y género. A veces los indígenas encabezan demandas sociales, pero en otros momentos pujan por modificar la forma Estado e, incluso, se expresan como trabajadores campesinos en lucha por la tierra. Las mujeres se movilizan por la memoria (por ejemplo, las Madres y Abuelas de Plaza de Mayo en Argentina), pero también lo hacen por el territorio y en contra del avance extractivista (por ejemplo, las Madres de Barrio Ituzaingó Anexo en Córdoba-Argentina, emblemas de la lucha por la justicia ambiental) y en ambos casos trasladan una situación personal (ser madre) al ámbito de lo público, haciendo de lo personal un asunto eminentemente político y con vocación de transformación social.

Un mapeo más completo, aunque preservando el carácter ilustrativo de los ejemplos que citamos ${ }^{16}$, podría construirse si también se incluyen los repertorios de las protestas. Estos se entienden como los formatos en que se visibiliza la acción colectiva (Tarrow, 1997); es decir, el modo en que se presentan las demandas en la escena pública (pudiendo ser una huelga, corte de ruta o manifestación, entre muchas otras modalidades). Los repertorios impregnan a las protestas de esté-

16 Los casos y situaciones que aquí se mencionan son solo una muestra de la diversidad de experiencias de la región, estos se citan como ejemplos ilustrativos de las dimensiones teóricas que sistematizamos. 
ticas particulares y, por lo general, no se presentan aisladamente, sino que aparecen combinados y articulados con una diversidad de métodos y contextos. Entre los formatos más recurrentes podrían destacarse la huelga, los paros cívicos, las movilizaciones y manifestaciones, caminatas indígenas, abstencionismo electoral, escraches, bloqueos de caminos, cacerolazo y manifestaciones online. Los revisaremos en detalle en las siguientes páginas.

La huelga continúa siendo la modalidad más utilizada, y es la expresión más antigua de la protesta social en el Estado moderno. Consiste en la abstención de realizar las actividades laborales que regularmente se desarrollan. Está fuertemente asociada con el primer grupo de demandas y, en especial, con las reivindicaciones en torno al trabajo. Además, es característica de actores colectivos con un nivel de organización formal o institucionalizado. En la historia de la región diversas huelgas han trascendido por su destacada impronta y capacidad de movilización, aunque también por la virulencia de la reacción de los gobiernos vía uso de la fuerza. Ejemplo de ello son los fusilamientos en la Patagonia argentina ante la huelga, principalmente de los peones de las estancias de la provincia de Santa Cruz, en 1921; o las matanzas en el municipio colombiano de Ciénaga ante la huelga de los trabajadores de las plantaciones de banano de la United Fruit Company, en 1928. Actualmente se apela a esta medida con recurrencia: huelga de los maestros, de los bancarios, de los trabajadores del sistema de salud, entre otras; por lo general, en reacción al deterioro salarial ante medidas de ajuste, crecimiento de la inflación o situaciones de recesión económica.

Los paros cívicos son una forma especialmente amplia y frecuente de protesta, que consiste en la paralización de las actividades como manera de ejercer presión, por lo general, a los gobiernos o a algún poder público específico, con demandas que trascienden la cuestión laboral. Habitualmente los paros cívicos se ven acompañados de movilizaciones callejeras, más o menos esporádicas, simultáneas o incluso de carácter nacional. De acuerdo con Jorge Iván Bonilla y María Eugenia García Raya (1997) los paros cívicos son:

conflictos que dan forma y rostro a una serie de demandas sociales que van desde la protesta por la ineficiente prestación de servicios públicos domiciliarios, la ausencia de políticas públicas de desa- 
rrollo local y regional, la construcción de vías, la distribución y dotación de servicios de salud y educación, hasta la solicitud de paz con los sectores armados, el respeto a los derechos humanos y a las autonomías individuales, entre otras (p. 65).

Estos paros, entonces, no están asociados a una demanda concreta. Dos ejemplos podrían ilustrar mejor este punto. El primero, remite a los paros realizados por los capitalistas, los llamados lockout patronales, una medida de acción directa que consiste en la paralización total o parcial de las actividades de uno o varios establecimientos o actividades económicas, por decisión del empresario o patrón. En efecto, estos paros son las "huelgas de los empleadores" aunque el término (huelga), tal como vimos antes, está más asociado a los reclamos de los trabajadores. El segundo ejemplo refiere a los paros nacionales de mujeres, los cuales se orientan a una paralización no solo en actividades laborales del sector público o privado de las mujeres, sino también en el trabajo informal, precarizado, o mal registrado (como las empleadas domésticas) y tareas de cuidado en el ámbito del hogar (limpieza, atención de niños y/o adultos mayores). Dichos paros han sido acompañados de grandes movilizaciones en diversos centros urbanos, ciudades intermedias y pequeñas poblaciones de América Latina. En el 2017 y el 2018, por ejemplo, los paros de mujeres adquirieron carácter internacional, con el llamado Paro Internacional de Mujeres (PIM), en inglés International Women's Strike (IWS), o el conocido 8M.

Las movilizaciones y manifestaciones, en tanto, designan una modalidad que procura alcanzar amplia visibilidad en el espacio público, y se utiliza para reivindicar un gran abanico de demandas especialmente en el ámbito urbano: la paz en contextos de hostilidad y terror, los derechos humanos, la equidad de género, la defensa del medio ambiente, la vivienda y el trabajo, entre tantas otras. La manifestación callejera podría entenderse, entonces, como "ocupación momentánea, por varias personas, de un lugar abierto, público o privado, y que directa o indirectamente conlleva la expresión de opiniones políticas" (Fillieulle, 1997, p. 44). Dos repertorios adicionales se encuentran asociados con las movilizaciones y manifestaciones, dependiendo del contexto y del contenido del reclamo: la estrategia del silencio, vinculada con entornos de represión o violencia, donde se acude a estéticas 
que representan una "sonoridad fúnebre", y la narrativa de fiesta como dispositivo comunicativo para expresar los reclamos desde el recurso del ruido y el color.

Es importante señalar que las movilizaciones pueden conformar un ciclo de acción colectiva prolongado durante un tiempo, lo que indica la proliferación de varias manifestaciones sucesivas e, incluso, con simultaneidad en distintos espacios. En esa línea, podrían interpretarse, por ejemplo, las activas jornadas de movilización en Brasil durante el año 2013 y 2014, protagonizadas por el Movimento Passe Livre (MPL) y los Comités Populares de la Copa ${ }^{17}$, que rechazaban los efectos de la recesión económica y la crisis urbana. Hacia el 2015 este grupo de protestas cuestionó el viraje hacia la derecha del nuevo gabinete de la entonces presidenta Dilma Rousseff (que incluía exponentes vinculados a la ortodoxia neoliberal y el agronegocio). También podría pensarse en un ejemplo aún más cercano en el tiempo, que remite a las masivas jornadas de movilización en Chile, desde octubre de 2019 hasta aproximadamente febrero de 2020. Dichas manifestaciones se erigieron en reacción inmediata al alza en la tarifa del sistema público de transporte de Santiago, pero en el trasfondo denunciaban el carácter excluyente del neoliberalismo y la permanencia de enclaves autoritarios en el sistema político chileno.

Las caminatas indígenas, por su parte, constituyen otro tipo de repertorio basado en la articulación entre una narrativa que expresa la continuidad de los atropellos a los derechos de los pueblos originarios desde tiempos de la Colonia hasta nuestros días, y una reivindicación puntual por temas como la vivienda, la tierra, el trabajo y contra la represión, entre otros. Estos actores procuran dar visibilidad a sus reclamos a través de caminatas que atraviesan diversas ciudades, localidades y pueblos hasta llegar, en la mayoría de los casos, a la capital de sus respectivos países. Una vez allí suelen concentrarse en la plaza principal y/o frente a las casas de gobierno, para hacer visible su presencia (y sus demandas) ante los ojos de los mandatarios y la sociedad en general. Este formato ha sido recurrente en la historia de las luchas

17 Eran espacios de coordinación de movilizaciones que se articularon en diferentes ciudades de Brasil y en los que participaban movimientos sociales, organizaciones civiles y sectores universitarios. Su objetivo era manifestarse en contra de diversas cuestiones relacionadas a la organización del Mundial de fútbol masculino FIFA en Brasil. 
del movimiento indígena en Bolivia; en el contexto reciente destacan las sucesivas Marchas Indígenas en defensa del Territorio Indígena y Parque Nacional Isiboro Sécure (TIPNIS) con amplia visibilidad y convocatoria a partir del 2011.

El abstencionismo electoral remite a un formato de protesta política al que suele apelarse cuando las bases de la democracia no son del todo sólidas y experimentan una crisis de legitimidad. Concretamente consiste en no realizar la acción de voto cuando los poderes públicos convocan a hacerlo, o - en todo caso- hacerlo a través del voto nulo, blanco o el llamado "voto bronca". Estas modalidades se emplearon, por ejemplo, en la coyuntura argentina de la crisis del 2001. Además de altos porcentajes de abstención a sufragar en la contienda parlamentaria argentina de octubre de 2001, un gran porcentaje de los electores se inclinó por el voto al personaje de historietas Clemente ("no roba porque no tiene manos") o por la imagen de un inodoro-cloaca ("a donde pertenecerían todos los políticos"), constituyéndose esas opciones en la primera minoría.

En cuanto a los escraches, estos designan un método especialmente vinculado con la demanda por los derechos humanos, y principalmente utilizado por los sectores más jóvenes de los colectivos que giran en torno a esa temática. Quizás el movimiento que más ha hecho uso de este repertorio es la agrupación HIJOS (Hijos por la Identidad y la Justicia contra el Olvido y el Silencio) de Argentina. La estética de esta forma de protesta está marcada por la concentración en el domicilio o en el lugar de trabajo de una persona que es denunciada por atentar contra los derechos humanos; se trata de hacer visible, a través de pintadas en los muros y expresión de repudios, la condena social a este tipo de actos.

Los bloqueos de caminos, en tanto, constituyen una modalidad que consiste en la obstrucción de la vía pública (accesos, puentes, rutas y/o calles) para visibilizar alguna demanda. A lo largo de la región han adquirido diversas denominaciones y estéticas. En Argentina, por ejemplo, los bloqueos son particularmente conocidos como piquetes, dando incluso nombre a un colectivo social heterogéneo que se formó al calor de la reivindicación de las fuentes de trabajo a fines de los años 90. Su metodología radica en la quema de cubiertas en lugares estratégicos para imposibilitar, total o parcialmente, la circulación por calles, 
caminos o rutas. Otra variante son los bloqueos hormiga, en Bolivia, los cuales consisten en trabar la movilidad a partir de esparcir distintos objetos (vehículos, cintas, piedras, entre otros) que entorpecen el paso.

También se destaca el repertorio del cacerolazo que se caracteriza por ser relativamente espontáneo y generalmente se configura contra alguna decisión de gobierno. La estética predominante es el ruido, ya que los ciudadanos asisten con cacerolas o cualquier utensilio de metal para producir el mayor barullo posible; el acuerdo previo suele estar en el horario de la concentración, aunque en ocasiones va acompañado de la permanencia en sectores clave de las ciudades. Este método suele estar más vinculado con movilizaciones de la clases altas y medias. Dos ejemplos resultan paradigmáticos: el primero ${ }^{18}$, refiere a los cacerolazos producidos en diciembre de 1971 en contra del gobierno de Salvador Allende (1970-1973) en Chile. En esa ocasión, mujeres y niños con el apoyo de actores de la derecha chilena (Partido Demócrata Cristiano, Partido Nacional, el movimiento Patria y Libertad, entre otros) se movilizaron con cacerolas para marcar su desaprobación frente a las políticas redistributivas del gobierno y los signos del desabastecimiento de productos.

El segundo ejemplo destacado, más cercano en el tiempo, remite a los cacerolazos contra el gobierno de Fernando de la Rúa (1999-2001) en el contexto de la crisis argentina de diciembre de 2001. Tal iniciativa concentró especialmente a sectores medios y ahorristas que se vieron afectados por las impopulares medidas adoptadas por el gobierno, entre ellas el llamado corralito u oficialmente denominado "intangibilidad de los depósitos bancarios”, que impedía la extracción de dinero en efectivo de los bancos. También es preciso mencionar que los ahorristas argentinos acudieron nuevamente a este repertorio para manifestar la disconformidad con el control para la compra de divisa extranjera durante la segunda presidencia de Cristina Fernández (2011-2015). En Brasil, las fuertes críticas al gobierno de Dilma Roussef, en 2015 y 2016, y el apoyo al pedido de destitución, estuvieron acompañados por este tipo de modalidad. En el escenario actual, signado por la proliferación del Coronavirus, los cacerolazos se hicieron visibles en las principales

18 En efecto, el caso chileno constituye la primera manifestación de este repertorio en América Latina. 
ciudades brasileñas para denunciar el deficiente manejo de la situación por parte del presidente Jair Bolsonaro.

Finalmente, las manifestaciones online designan los modos de protesta más actuales y que han ganado creciente protagonismo. Se basan en las narrativas multimediales sostenidas en las pantallas (computadora, tablet y celular) y la internet, con difusión de videos y participación activa en redes sociales. Este método es muy discutido, en tanto aún resulta poco claro su nivel de incidencia si lo consideramos aisladamente, es decir, más allá de la irrupción en el espacio público de manera física, y no solo virtual. Tal como mostraremos en el apartado siguiente, este repertorio cobró especial importancia en el marco de las restricciones al contacto social y la presencialidad física a causa de la pandemia.

En definitiva, este listado amplio, pero no exhaustivo, refleja la multiplicidad de formatos y metodologías en que se expresan las protestas sociales en nuestra región. Muchos de estos repertorios suelen combinarse entre sí, entrelazando sus estéticas y dinámicas. Al mismo tiempo, la elección de uno u otro método se relaciona con la racionalidad estratégica, pero también con las tradiciones, identidades e historias subjetivas de los individuos o grupos que protestan. Por último, la diversidad de ejemplos reafirma que las protestas pueden asociarse tanto a actores situados del lado menos favorable de la correlación de fuerzas - es decir, actores que disponen de menos recursos a la hora de protestar y que lo harían con un sentido de cambio social contrahegemónico-; como también, con aquellos sujetos que ostentan ciertos privilegios en el orden establecido y poseen alianzas estratégicas con las grandes empresas, gobiernos o medios de comunicación hegemónicos.

\section{La "nueva cuestión social", exploraciones sobre las protestas en tiempos de pandemia}

Las protestas sociales permiten, entonces, a través de sus demandas, pero también de sus repertorios y articulaciones, acercarnos a los temas, problemas y conflictos predominantes de la cuestión social en una coyuntura determinada. Por ejemplo, el protagonismo de protestas en torno al acceso al mercado laboral o al reconocimiento de formas de trabajo informal (catalogadas previamente como el primer grupo de demandas), estaría hablando de una sociedad principalmente signada por las problemáticas del desempleo y la pobreza; mientras 
que el predominio de protestas que reclaman por los derechos de tercera generación (catalogadas como cuarto grupo de demandas) podría indicar la emergencia de nuevas preocupaciones por el medioambiente, el consumo o la información. A su vez, por ejemplo, las protestas que expresan un conflicto con la ley o rechazos a las acciones de criminalización (segundo conjunto), podrían mostrar fuertes deficiencias en los sistemas jurídicos y su aplicación.

Por su parte, los repertorios empleados en las protestas también nos hablan de los recursos y tradiciones disponibles en una sociedad. Aquellos sectores que no son nuevos, pero que han cobrado creciente presencia pública en la actualidad, como la comunidad LGTBI+, muestran sus disidencias apelando a las movilizaciones masivas con ruido y colores. Los trabajadores formales, que hacen parte de organizaciones sindicales más tradicionales, combinan las huelgas con movilizaciones que exhiben banderas, bombos e identificaciones políticas. El dolor y la conmoción social que provocan ciertos hechos de inseguridad o represión estatal y/o paramilitar suelen asociarse al silencio y las antorchas, enlazándose con exigencias de justicia y memoria sobre sucesos similares ocurridos en el pasado.

En suma, las diferentes dinámicas que fueron adquiriendo las protestas sociales a lo largo del tiempo permitirían reconocer algunas demandas persistentes y otras novedosas, la continuidad de repertorios tradicionales y su combinación con formatos innovadores, la frecuente búsqueda por la mediación del Estado y las permanentes articulaciones con otros actores sociales y políticos; en ese camino también afloran viejos dilemas y nuevos desafíos. Ciertamente todo ello interpela la definición misma de la cuestión social y hace perceptible sus mutaciones y transformaciones.

Pierre Rosanvallon (2007) definió como "nueva cuestión social" a una nueva etapa de lo social a la que asistimos actualmente. Se trata de un periodo que inicia con la crisis del Estado de Bienestar o del llamado Estado de providencia. Hacia mediados del siglo XX, este modelo estatal sentó las bases de la sociedad aseguradora, la cual cubría los principales riesgos de la existencia humana (como la enfermedad a través de sistemas de salud pública, la desocupación con seguros de desempleo y políticas económicas proteccionistas, la vejez a través de sistemas previsionales y de seguridad social, la invalidez, entre otros). La técnica 
del seguro constituía una manera de gestionar riesgos previsibles y esperables de las sociedades capitalistas, aunque presentando fisonomías particulares en las distintas latitudes geográficas. Lo cierto es que, tanto en Europa como en América Latina, el Estado de Bienestar entró en crisis en los años 70, su declive se agudizó en los 80 y fue prácticamente desmantelado en los 90. En esta última etapa se produjo una separación progresiva de las nociones de seguro social y de solidaridad, y se ingresó en una nueva era que redefinió las reglas del "vivir juntos". A partir de entonces la noción de riesgo cambió de escala y es allí donde entra en escena la llamada nueva cuestión social, como "nueva era de lo social" en la que aparecen formas de inseguridad inéditas: la delincuencia urbana, rupturas familiares, inseguridad económica, catástrofes naturales, riesgos de orden global que ponen en jaque las soluciones que pueden aportar los Estados nacionales, entre otros (Rosanvallon, 2007).

Creemos que estas reflexiones son de especial importancia para la compresión de los cambios y desafíos que conlleva la actual expansión planetaria del Coronavirus. La infección respiratoria que provoca el nuevo virus no cuenta aún con respuestas para su prevención y su cura (por ejemplo, una vacuna capaz de inmunizar a las personas), y el movimiento constante de los individuos por todo el mundo ha potenciado su alta capacidad de contagio. De este modo, la pandemia pone de manifiesto la presencia de problemas que trascienden fronteras, y que exceden la capacidad de las organizaciones internacionales y de los Estados nacionales para brindar soluciones efectivas.

Frente a esta situación de riesgos inéditos y de escalas sin precedentes, diferentes gobiernos de nuestra región dispusieron medidas excepcionales de aislamiento y distanciamiento social preventivo para regular el flujo poblacional y limitar el desarrollo de las actividades socioeconómicas. Si bien esto ha permitido a algunos gobiernos controlar la curva de contagios y ganar tiempo para fortalecer los resentidos sistemas de salud; también repercutió en la agudización de problemas económicos previos (la recesión, el aumento generalizado de precios, el fuerte peso de las deudas contraídas con organismos multilaterales de crédito, entre otros) y sus consecuencias impactan sobre un tejido social ya lesionado.

La pandemia provoca, entonces, reconfiguraciones en la definición de la nueva cuestión social, potenciando la sensación de inseguridad inédita (Rosanvallon, 2007) y profundizando las vulnerabilidades pre- 
viamente existentes (de Sousa Santos, 2020). Ello, sin dudas, repercute en los actores movilizados quienes, como dijimos, pujan para que sus demandas sean visibles y se tornen en problemas públicos inscritos en las agendas de los gobiernos y las sociedades de la región.

Retomando una inquietud inicial de este texto, vale preguntarse por las demandas y los repertorios de las protestas sociales en tiempos de pandemia, sobre todo cuando las mismas habían adquirido fuerte y creciente protagonismo. Al respecto, cabe considerar que en el 2019 se registraron altos niveles de conflictividad social, con multiplicidad de protestas y estallidos sociales ante la reedición de medidas de ajuste (especialmente en Chile, Colombia y Ecuador); masivas manifestaciones ante declaraciones agraviantes y hechos de corrupción (en Puerto Rico y Brasil, por ejemplo), e incluso numerosas iniciativas en reacción a la destitución de un gobierno democráticamente electo (en Bolivia). Ese ciclo se vio interrumpido, o cuanto menos resignificado, a raíz de la nueva coyuntura.

La pandemia y los escenarios venideros, que se han popularizado como de una "nueva normalidad", amenazan con profundizar los problemas denunciados previamente por una amplia diversidad de actores colectivos: mayor precariedad laboral, creciente degradación socioambiental, expansión de la desigualdad, y proliferación de discursos de regresión política que acentúan el miedo y la xenofobia. Inicialmente podríamos pensar que, al menos, tres ejes aparecen como nodales en el reciente devenir de las protestas sociales.

Por un lado, se expanden las demandas vinculadas al trabajo, ya que los efectos económicos de la pandemia provocaron el aumento de los despidos, el deterioro de los salarios, la precarización laboral, y la extensión generalizada del no regulado teletrabajo. Ante esta situación alcanzaron amplia difusión las protestas por medios virtuales con jornadas de visibilización en redes sociales, tuitazos masivos, asambleas por plataformas digitales, entre otras. En el inicio de la crisis sanitaria, las marchas y manifestaciones de calle se vieron fuertemente resentidas, y con el tiempo se modificaron procurando resguardar el distanciamiento social entre los participantes y el uso de barbijos o mascarillas.

El segundo gran eje articulador de las protestas remite a la denuncia de la degradación y devastación socioambiental que revela con 
mayor magnitud la diseminación del virus. Procurar que esta temática adquiera visibilidad en las agendas públicas, y especialmente gubernamentales, se convierte en el gran desafío para la movilización social contemporánea. Al respecto, Svampa y Viale (2020) postulan la necesidad de un "Gran Pacto Ecosocial y Económico", orientado hacia la reconfiguración integral, esto es, social, sanitaria, económica y ecológica, que tribute a la vida y a los pueblos.

En tercer lugar, la lucha por la supervivencia se agudiza, buscando extender las acciones colectivas y las redes de solidaridad para ofrecer respuestas ante el hambre, la deficiencia en la atención médica, y la falta de condiciones mínimas de higiene y salubridad. De este modo, se apela a las ollas populares, las cadenas de acopio de mercadería, la distribución de bolsones con alimentos, y la atención casa por casa frente a la imposibilidad de acudir a los comedores y merenderos comunitarios.

Tal como señala de Sousa Santos (2020) las condiciones para las fuerzas populares no resultan nada favorables ante la expansión del Coronavirus. Primero, porque en efecto es difícil protegerse cuando no hay condiciones de protección posible pensando, por ejemplo, en los barrios más humildes de las grandes urbes latinoamericanas o en la situación de pueblos indígenas y afrodescendientes, los cuales afrontan cotidianamente problemáticas asociadas a la pobreza, el hacinamiento y las dificultades para el acceso al agua potable. Luego, por el riesgo al reforzamiento autoritario de los Estados y las fuerzas de seguridad que extreman las medidas de control y la recurrencia a la coerción para tal fin. Y, en tercer lugar, por el recrudecimiento de la crisis económica, con consecuencias aún más perjudiciales en aquellos países cuyos gobiernos han sido reticentes a la intervención estatal.

No obstante, y de acuerdo con lo que hemos señalado en apartados anteriores, las protestas no resultan patrimonio de ningún sector social; y en el contexto actual también se han manifestado diversos actores, en un abanico bien heterogéneo, que expresan su disconformidad con las medidas excepcionales de aislamiento y distanciamiento social acordadas por los gobiernos. Dichos grupos se conocen popularmente como "anticuarentena", quienes toman la calle y se movilizan apelando a símbolos de unidad nacional y exaltando el valor de la libertad. En general, estas manifestaciones han sido promovidas por sectores de la actividad econó- 
mica (en especial del medio agropecuario, comercial e industrial), opositores a los gobiernos identificados como progresistas; como también por agrupaciones civiles de tradición conservadora y vinculadas con los partidos de derecha, quienes tomaron el espacio público y, ciertamente, aprovecharon la ausencia en las calles de las organizaciones y movimientos sociales. Algunos ejemplos son las movilizaciones llevadas a cabo por la agrupación "Un solo Uruguay" en el 2018 y 2019, y las recientes marchas y cacerolazos "anticuarentena" llevados a cabo en Argentina.

\section{Consideraciones finales}

Quizás el elemento más contundente de las líneas aquí desplegadas da cuenta de los vínculos y prácticas que se entretejen en la calle, los barrios, las plazas, en el espacio público-político, para visibilizar demandas insatisfechas. Quienes protestan lo hacen en el marco de las reglas de la democracia y, generalmente, expresan una demanda clara: piden los oídos institucionales, piden mesas de negociación, piden ser vistos y tratan con repertorios más o menos novedosos de hacer visible un sujeto político; al tiempo que traen a escena alternativas a los modos hegemónicos de organización y acción. Así, las mujeres, los indígenas, los desempleados, los precarizados, entre tantos otros actores colectivos, impulsan grandes manifestaciones y concentraciones; realizan ferias, cortes y acampes; se reúnen en asambleas y paros ciudadanos; despliegan sus fuerzas en los barrios, ciudades y rutas del continente; e, incluso, pueden abstenerse de participar cuando los gobiernos llaman a hacerlo y expresan (física o virtualmente) su veto ante determinadas medidas.

Sin embargo, como señalamos antes, las protestas no son patrimonio de los actores en resistencia, las derechas y sectores conservadores se han visibilizado en distintas movilizaciones y manifestaciones en el marco de la pandemia. Estos sectores enarbolan banderas de unidad nacional y valores tradicionales, a través de los cuales expresan una sensibilidad pro status quo y un particular rechazo a las medidas de aislamiento social y preventivo, a través de la defensa del falso dilema entre economía y salud o economía y vida ${ }^{19}$.

19 Para un análisis crítico que, desde una perspectiva heterodoxa de la economía, deconstruye el falso dilema entre economía, salud y vida, véase: Katz (2020). 
En suma, las protestas sociales atañen a lo político, lo comunicativo, lo histórico y lo territorial. Es en este espacio de tensión-articulación que deberían situarse los intentos por comprenderlas. De modo que pensar las protestas sociales en vinculación - y no en oposición con la democracia-, también habilita a incentivar y potenciar los procesos de lucha por los derechos y su apropiación subjetiva y objetiva en los diversos territorios que analizamos, habitamos y trabajamos. En ese camino, no podríamos perder de vista que su devenir constituye un elemento clave para dar cuenta de los tiempos que vivimos, nutriendo las prácticas de intervención territorial y los mecanismos de participación democrática.

Claramente, las reflexiones de este artículo no constituyen respuestas cerradas, sino más bien intentos limitados por ordenar y sistematizar un abanico diverso de lecturas e interpretaciones pertinentes para el análisis de las protestas sociales. Al mismo tiempo, se trata de una invitación al debate y a la apertura de nuevos interrogantes o, quizás, a la renovación de "viejas" preguntas a la luz de renovados contextos. Entre las líneas a profundizar en trabajos futuros, cabe considerar: ¿Cuáles son las dinámicas internas de los grupos demandantes? ¿Qué relación hay entre el acceso a los recursos y el éxito de las protestas? ¿Qué rol juegan los medios de comunicación y los gobiernos en limitar o favorecer el accionar colectivo? ¿Cuáles son las alternativas de intervención territorial y comunitaria a las que apelan los colectivos que protestan en un contexto de pandemia?

En última instancia, la difícil coyuntura regional actual, en términos de indicadores macroeconómicos negativos y consecuencias sociales altamente perjudiciales para las mayorías populares -agravadas por la reciente expansión del Coronavirus-, requiere redoblar esfuerzos en el campo de las protestas en resistencia. Esto es, se necesita consolidar lazos de solidaridad y equivalencias hacia el interior de los grupos y movimientos sociales, divisar objetivos y antagonistas comunes, y gestar proyectos con capacidad de agregación y de disputa para definir los temas y problemas que incluirán en sus agendas públicas la sociedad en general y los gobiernos en particular. 


\section{Referencias}

Andújar, A. y Bohoslavsky, E. (Eds.) (2020). Todos estos años de gente: historia social, protesta y política en América Latina. Buenos Aires: Universidad Nacional de General Sarmiento.

Ansaldi, W. (2017). Arregladitas como para ir de boda. Nuevo ropaje para las viejas derechas. Theomai, 35, 22-5. Recuperado de http://www.revista-theomai.unq.edu.ar/numero35

Auyero, J. (2002). La protesta. Retratos de la beligerancia popular en la Argentina democrática. Buenos Aires: Libros del Rojas.

Basconzuelo, C. (2020). La visibilidad de la protesta: una expresión del conflicto social. En D. Michelini, C., Basconzuelo, G. Pérez Zavala, y N. Galetto (Eds.), Conflictos sociales y convivencia democrática (pp. 35-38). Río Cuarto: Ediciones del Icala.

Bonilla, J. I. y García Raya, E. (1997). Espacio público y conflicto en Colombia. El discurso de prensa sobre la protesta social. El Tiempo 1987-1995. Revista Signo y Pensamiento, 16(30), 6176. Recuperado de https://dialnet.unirioja.es/servlet/articul $o$ ?codigo $=4368310$ \&orden $=0$ \&info $=$ link

Botero, C. (2011) Entrevista a la relatora especial para la libertad de expresión de la Comisión Interamericana de Derechos Humanos de la OEA. En E. Rabinovich et al. (Eds.), "Vamos a portarnos mal". Protesta social y libertad de expresión en América Latina (pp. 57-59). Bogotá: Centro de Competencia en Comunicación C3, Fundación Friedrich Ebert y Asociación por los Derechos Civiles.

Calderón Gutiérrez, F. (Coord.) (2012). La protesta social en América Latina. Cuaderno de Prospectiva Política 1. Buenos Aires: Siglo XXI.

Carballeda, A. (2015). El territorio como relato. Una aproximación conceptual. Revista Margen, 76, Recuperado de http://www. margen.org/carballeda/Politica\%20Social\%20y\%20Cuestion\%20Social.pdf

Castel, R. (1997). La metamorfosis de la cuestión social. Buenos Aires: Paidós.

De Sousa Santos, B. (2007). Una reflexión sobre los nuevos movimientos sociales. En Resistencias, luchas emancipatorias y la cuestión de la alternativa (s/p). Centro Cultural de la Cooperación Floreal Gorini (CCC). 
De Sousa Santos, B. (2020). La cruel pedagogía del virus. Buenos Aires: Consejo Latinoamericano de Ciencias Sociales, CLACSO.

Fillieule, O. (1997). Stratégies de la rue. París: Presses de Sciences Po.

Giordano, V. (2014). “¿Qué hay de nuevo en las 'nuevas derechas’?” Nueva Sociedad, 254, 46-56. Recuperado de https://nuso. org/articulo/que-hay-de-nuevo-en-las-nuevas-derechas/

Grassi, E. (2003). Políticas y problemas sociales en la sociedad neoliberal. La otra década infame I. Buenos Aires: Espacio Editorial.

Katz, C. (2020). La pandemia que estremece al capitalismo (I). Recuperado de https://www.cadtm.org/La-pandemia-que-estremece-al-capitalismo-I

Laclau, E. y Mouffe, Ch. (2004). Hegemonía y estrategia socialista. Madrid: Siglo XXI.

Laclau, E. (2005). La razón populista. Buenos Aires: Fondo de Cultura Económica.

Laclau, E. (2006). La deriva populista y la centro izquierda latinoamericana. Nueva Sociedad, 205, 56-61. Recuperado de https:// nuso.org/media/articles/downloads/3381_1.pdf

López Maya, M. (2000). La protesta popular en la Venezuela contemporánea. Enfoque conceptual, metodológico y fuente. En J. Á. Rodríguez (Comp.), Visiones del oficio. Historiadores venezolanos en el siglo XXI (pp. 399-412). Caracas: Academia Nacional de la Historia/Facultad de Humanidades y Educación, Universidad Central de Venezuela, UCV.

López Segrera, F. (2016). América Latina: crisis del posneoliberalismo y ascenso de la nueva derecha. Buenos Aires: Consejo Latinoamericano de Ciencias Sociales, CLACSO.

McAdam, D., McCarthy, J., y Zald, M. (1999). Movimientos sociales: perspectivas comparadas. Madrid: Istmo.

Magrini, A. L. (2011). La efervescencia de la protesta social. De luchas, demandas, narrativas y estéticas populares. En E. Rabinovich et al. (Eds.), "Vamos a portarnos mal." Protesta social y libertad de expresión en América Latina (pp. 31-52). Bogotá: Centro de Competencia en Comunicación C3, Fundación Friedrich Ebert y Asociación por los Derechos Civiles.

Marchart, O. (2009). El pensamiento político posfundacional. La diferencia politica en Nancy, Lefort, Badiou y Laclau. Buenos Aires: Fondo de Cultura Económica. 
Melucci, A. (1994). Asumir un compromiso: identidad y movilización en los movimientos sociales. Revista Zona Abierta, 69, 153-180.

Quiroga, M. V. y Juncos, L. (2020). Protestas sociales en Brasil: entre el repliegue del progresismo y el ascenso de las derechas, 20142018. Estado \& Comunes, Revista de Politicas y Problemas Públicos, 10, 53-72. Recuperado de http://revistas.iaen.edu.ec/ index.php/estado_comunes/article/view/149/238

Quiroga M. V., Brizzio, M., y Forlani, N. (2018). Las organizaciones piqueteras y los virajes políticos en Argentina. Espacio Abierto, 27(3), 27-48. Recuperado de https://www.produccioncientificaluz.org/index.php/espacio/article/view/29765/30725

Quiroga, M. V. (2013). Perspectivas para el análisis de la acción colectiva: algunas reflexiones críticas y posibles aportes desde la teoría de la hegemonía. Araucaria, 15(30), 25-44. Recuperado de https://revistascientificas.us.es/index.php/araucaria/ article/view/2200

Quiroga, M. V. (2017). Identidades políticas y movilización social. Un estudio comparado de la CTA en Argentina y del MAS-IPSP en Bolivia en la transición del siglo XX al XXI. Córdoba: Editorial Universitaria Villa María.

Rincón, O. y Magrini, A. L. (2010). Medios, poder y democracia en América Latina. De celebrities políticas, poderes mediáticos y democracias de simulación. En B. Sorj, (Comp.), Poder político y medios de comunicación: de la representación política al reality show (pp. 101-137). Buenos Aires: Siglo XXI.

Rincón, O. y Magrini, A. L. (2011). La mediática del poder como lucha por la hegemonía del proyecto político. En A. Rettberg y O. Rincón (Eds.), Medios, democracia y poder. Una mirada comparada desde Colombia, Ecuador, Venezuela y Argentina (pp. 175-195). Bogotá: Universidad de los Andes, Centro de Estudios Socioculturales e Internacionales (CESO), Centro de Estudios de Periodismo (CEPER).

Ramírez Gallegos, F. (2006). Mucho más que dos izquierdas. Nueva Sociedad, 205, 30-44. Recuperado de http://nuso.org/media/ articles/downloads/3379_1.pdf

Rosanvallon, P. (2007). La nueva cuestión social. Repensar el Estado de providencia. Buenos Aires: Manantial. 
Schuster, F. (2005). Las protestas sociales y el estudio de la acción colectiva. En F. Schuster et al. (Comps.), Tomar la palabra: Estudios sobre protesta social y acción colectiva en Argentina contemporánea (pp. 43-83). Buenos Aires: Prometeo.

Souza Coêlho Neto, A., Basconzuelo, C., y Quiroga, M. V. (Orgs.) (2016). Ação coletiva e territorialidade: dinâmicas, práticas, significados abordagens. Salvador: Editora da Universidade do Estado da Bahia, EDUNEB,

Svampa, M y Viale, E. (2014). Maldesarrollo. La Argentina del extractivismo y el despojo. Buenos Aires: Katz.

Svampa, My Viale, E. (2020). Hacia un gran pacto ecosocial y económico. En A. Grimson (Ed.), El futuro después del COVID-19 (pp. 97-104). Buenos Aires: Presidencia de la Nación.

Svampa, M. (2006). Movimientos sociales y nuevo escenario regional: inflexiones del paradigma neoliberal en América Latina. Cuadernos de Socio-Historia, 19/20, 40-55. Recuperado de http://www.memoria.fahce.unlp.edu.ar/art_revistas/ pr.3612/pr.3612.pdf

Svampa, M. (2008). Cambio de época. Movimientos sociales y poder político. Buenos Aires: Siglo XXI.

Svampa, M. (2012). Consenso de los commodities, giro ecoterritorial y pensamiento crítico en América Latina. Observatorio Social de América Latina, OSAL, 13(32), 15-38. Recuperado de http://biblioteca.clacso.edu.ar/clacso/ osal/20120927103642/OSAL32.pdf

Tamayo, S. (2016). Espacios y repertorios de la protesta. México D. F.: Red Mexicana de Estudios de los Movimientos Sociales.

Traugott, M. (2002). Protesta social. Barcelona: Hacer.

Tarrow, S. (1997). El poder en movimiento. Los movimientos sociales, la acción colectiva y la política. Madrid: Alianza.

Tilly, C. (1978). From mobilization to revolution. New York: McGrawHill.

Tilly, C. (1990). Modelos y realidades de la acción colectiva popular. Revista Zona Abierta, 54/55, 167-195.

Touraine, A. (1997). ¿Podremos vivir juntos? Buenos Aires: Fondo de Cultura Económica. 